\title{
Impact of Abattoir Effluent on Microbiological and Physicochemical Properties of Water Bodies: A Case Study of Yenagoa Metropolis, Nigeria
}

\section{Idisi $\mathrm{J}^{\mathbf{1}}$ and Uguru $\mathrm{H}^{2 *}$}

${ }^{1}$ Department of Civil Engineering Technology, Delta State Polytechnic, Ozoro, Nigeria ${ }^{2}$ Department of Agricultural and Bio-environmental Engineering Technology, Delta State Polytechnic, Ozoro, Nigeria

*Corresponding Author: Uguru H, Department of Agricultural and Bioenvironmental Engineering Technol ogy, Delta State Polytechnic, Ozoro, Nigeria.

DOI: $10.31080 /$ ASNH.2020.04.0646
Received: February 05, 2020

Published: February 14, 2020

(C) All rights are reserved by Idisi J and Uguru H.

\section{Abstract}

This study was carried out to assess the impact of abattoir effluent on some physicochemical and microbiological properties along the course of River Brass, in Bayelsa State, Southern Nigeria. Water samples were collected at four points at equidistance away from the effluent discharge point, along the course of the river, coded and taken immediately to the laboratory for water analysis. The tests were carried in accordance to American Public Health Association (APHA) standard recommended procedures. Results obtained from the tests showed that discharging the abattoir effluent into the water body had significant effect on the water physicochemical

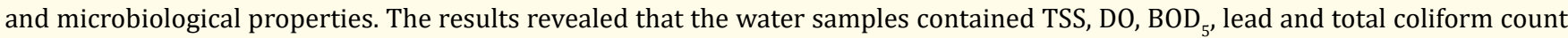
above the permissible limits recommended by World Health Organization and Nigerian Standard for Drinking Water. Highest mean values of total suspended solid (140 $\left.\mathrm{mg} \mathrm{l}^{-1}\right)$, dissolved oxygen (1.01 $\left.\mathrm{mg} \mathrm{l}^{-1}\right)$, biochemical oxygen demand (323 mg $\left.\mathrm{l}^{-1}\right)$, total coliform count (201 cfu ml-1), lead $1.09 \mathrm{mg} \mathrm{l}^{-1}$ ) and Ammonia (4.88 $\mathrm{mg} \mathrm{l}^{-1}$ ) was recorded at the abattoir effluent discharge point; and the values decreased in a fluctuating pattern as the river water flowed downstream. The results further revealed the importance of avoiding indiscriminate discharging of untreated effluents on the environment, mostly water bodies.

Keywords: Abattoir; Bayelsa; Effluent; Meat Processing; Water Quality

\section{Introduction}

An abattoir is any place, with the required facilities put in place used for or in connection with the slaughtering of farm animals, with the aim of producing meat intended for human consumption $[1,2]$. Animal processing is fast becoming lucrative business in $\mathrm{Ni}$ geria, partly due to the restriction on the importation of processed animal products into the country. Livestock industry in Nigeria provides domestic meat supplies to over 150 million people, and the same time provides employment opportunities for the teaming population $[3,4]$. Meat processing usually required large volume of water required, therefore most abattoirs are sited near water bodies like rivers, lakes, dams, etc., in order to have easy access to the water required [4]. Globally, Abattoirs are major source of environmental pollution, either directly or indirectly [2,4]. Agricultural waste materials usually produced in a tropical abattoir include bones, fat, hairs, feathers, fur, manure, undigested feed, animal body fluids (effluent), etc. [5].

The availability of safe and uncontaminated water is important for general public health; no matter its application (drinking, domestic use, food production or recreational purposes). According to World Health Organization (WHO), a country's economy can be boosted through better water resources management, mostly in the area of water supply and sanitation, and can contribute greatly to poverty alleviation [6]. Availability of clean water supply is one major concern in most parts of the world, especially in develop- ing and underdevelopment countries of the world [7]. About 785 million (about 13\%) of the world 6.8 billion population lack safe drinkable water, this figure includes 144 million population that are dependent on surface water. Nigeria is among four West African countries where less than half of the population can access safe drinking water, according to the United Nations data [8]. Due to the scarcity of drinking water in most parts of the world, mostly in Africa countries, the United Nations General Assembly (UNGA) in 2010 explicitly recognized access to safe water and sanitation as fundamental human right. Therefore, everybody has the right to sufficient, continuous, safe, acceptable, physically accessible, and affordable water for personal and domestic use [9].

Industrial and domestic effluents can contribute major health hazard to the public if not properly treated (managed) before they are discharged into the environment. Water quality is drastically affected by untreated effluents discharged directly into the environment, which later find their ways to the water bodies $[10,11]$. In most developing and under-developed countries, effluent obtained from agricultural products processing, industrial and domestic activities are discharge into water bodies without proper treatment. This attitude had led to about $80 \%$ occurrences of endemic and epidemic gastrointestinal (cholera, diarrhoea, dysentery, hepatitis A, typhoid, and polio) diseases in the world, mostly in Nigeria $[8,9,12]$. Even though diarrhoea is a highly preventable disease, approximately 829000 people die every year from diarrhea globally; 
this includes about 300,000 children under the aged of 5 years, which is linked to unsafe drinking water and poor sanitation [6]. Onifade., et al. [12] and Eboibi., et al. [13] stated that the rate of pollution of the water bodies through effluent discharged is highly dependent on the physicochemical and biological composition of the effluent, concentration of the effluent, distance from the point of discharge (contamination) and transportation medium (material medium through which the effluent travels). According to Uguru and Obah [14] cassava effluent had cyanide, nickel, zinc, and Total Coliform count concentration of $3.33 \mathrm{mgl}^{-1}, 2.12 \mathrm{mg}^{\mathrm{l}-1}, 10.95 \mathrm{mgl}^{-1}$, $133 \mathrm{cfu} \mathrm{ml}^{-1}$ respectively. Sumayya., et al. [15] reported abattoir effluent contains Phosphorus $0.143 \mathrm{mg} \mathrm{kg}^{-1}$, potassium $3.88 \mathrm{mg} \mathrm{kg}^{-1}$, calcium $0.29 \%$, Magnesium 1.30\%, dissolved oxygen (DO) 13.89 $\mathrm{mg} \mathrm{l}^{-1}$, and BOD $11.12 \mathrm{mg} \mathrm{l}^{-1}$.

It has become important to protect the water bodies like rivers, lakes, dams, etc. from contamination, and remediate the existing polluted ones; due to the scarcity of safe water being experienced globally. It has be established by researchers that water bodies are being continuously subjected to dynamic change with respect to the geological age, geochemical characteristics and anthropogenic influences [16]. Some researchers have studied on the effects of abattoir effluent on the environment. Abubakar and Tukur [2] reported that discharge (effluent) from abattoir significantly ( $\mathrm{p}<$ 0.05) effects some of the soil physiochemical properties. Rabah., et al. [17], in their research observed that the mean value of available phosphorus in abattoir effluent contaminated soil was higher (5.60 $\left.\mathrm{mgg}^{-1}\right)$, when compared to the results obtained for the uncontaminated soil (5.20 mgg-1). According to Neboh., et al. [4], the organic carbon and organic matter percentage recorded in abattoir effluent contaminated soil was higher when compared to the values obtained from the uncontaminated soil. Even though many researchers have worked on the effect of abattoir effluent on the environment, there is no reported literature from the Swali region of Bayelsa State, Southern Nigeria. Therefore, the aim of this research is to study the effect of abattoir effluent on Swali River in Bayelsa State, looking at the possible remedies in order to make possible recommendations.

\section{Materials and Methods}

Study area

The study area is located at Swali Market along River Brass in Bayelsa State, southern Nigeria. The coordinates of study area was captured and registered using a hand-held global positioning system (GPS) receiver. According to the values obtained from the GPS receiver, the study area was located between latitude $04^{0} 54,636^{1}$ and $04^{0} 54,859^{1}$ North and longitude $006^{0} .16,059^{1}$ and $006^{0} .15,970^{1}$ East of the Greenwich Meridian. According to the national population census figure of 2006, Swali has a population of 736,113 people. The abattoir is divided into two major different sections: the slaughtering section, where the animals are slaughtered; and the washing section where all the animal parts are cleaned. The slaughtering section was upland, while the river was used as the washing section. About 200 cows are killed weekly, and most of the wastes (mostly during the washing of the beef and intestines), are discharged directly into the river water untreated.

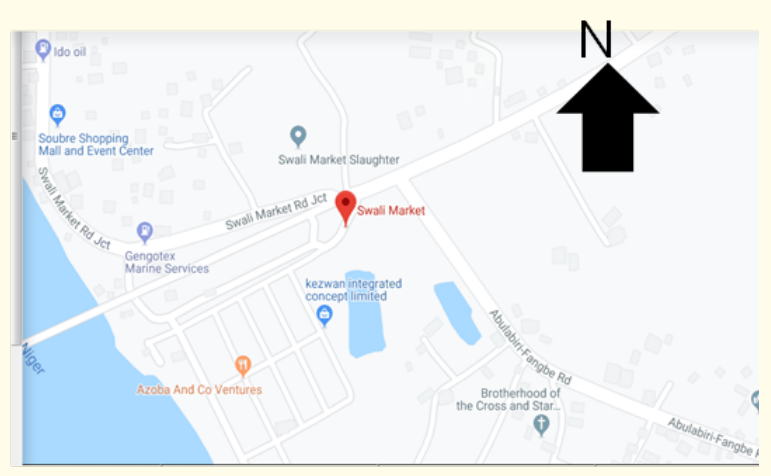

Figure 1

Source: Google Map [18].

Water samples collection

The water samples were collected from five spatial points across the study area (River Brass). Sample A was collected directly from the source of the discharge point (coordinates $04^{0} 54,859^{1}$ $\mathrm{N}$ and $006^{0} .15,970^{1} \mathrm{E}$ ); Sample B was collected $10 \mathrm{~m}$ away from the discharge point (coordinate $04^{0} 54,886^{1} \mathrm{~N}$ and $006^{0} .15,956^{1}$ E); sample C was collected $20 \mathrm{~m}$ from the discharge point, and 10 $\mathrm{m}$ away from point $\mathrm{B}\left(04^{0} 54,817^{1} \mathrm{~N}\right.$ and $\left.006^{0} .15,944^{1} \mathrm{E}\right)$; sample D was collected $10 \mathrm{~m}$ away from point $\mathrm{C}$ along the direction of flow of the river (coordinates $04^{0} 54,778^{1} \mathrm{~N}$ and $006^{0} 15,997^{1} \mathrm{E}$ ); while sample $\mathrm{E}$ was collected $10 \mathrm{~m}$ away from point $\mathrm{D}$ but very close to the river bank (coordinates $04^{0} 54,636^{1} \mathrm{~N}$ and $006^{0} 16,059^{1} \mathrm{E}$ ). Sampling was done during the rainy season (April, 2019), when the water volume and the flow rate of the river were high. Sterilized auto clave bottles were used to collect the water samples from these spatial points. The collected water samples were stored in the refrigerator at a temperature of $4^{\circ} \mathrm{C}$ and analyze within $24 \mathrm{~h}$.

Physicochemical analyses Water $\mathrm{pH}$ test

The $\mathrm{pH}$ analysis of the water samples were measured at the Biomaterial Laboratory of Delta State Polytechnic, Ozoro, Nigeria. Digital pH meter (model PHS-25), manufactured in China was used for the water $\mathrm{pH}$ analysis. For each test, the water sample was poured into a glass $250 \mathrm{ml}$ beaker (Pyrex model), and a $\mathrm{pH}$ meter probe was inserted into the water sample inside the beaker. The $\mathrm{pH}$ value of the water sample was then displayed on the $\mathrm{pH}$ meter screen, from where it was copy and recorded. According to recommended standard, the $\mathrm{pH}$ meter was standardized by using a buffer solution prior to each use [19].

\section{Electrical conductivity}

The electrical conductivity of the water samples was measured by employing the use of a digital electrical conductivity meter (model DDS-307) manufactured in China. For each test, the water sample was poured into a glass $250 \mathrm{ml}$ beaker (Pyrex model), and electrical conductivity meter probe was inserted into the water inside the beaker. The electrical conductivity value of the water sample was then displayed on the screen, from where it was copy and recorded. The electrical conductivity meter was standardized with 
distil water prior to each, and the meter was set at a temperature of $25^{\circ} \mathrm{C}$. This is because electrical conductivity of water is a function of temperature [19].

The other physicochemical analyses of the water samples were carried out in accordance to standard procedure recommended by American Public Health Association [10,20].

\section{Microbiological analyses}

The microbiological Analyses were carried out in accordance with standard methods recommended by American Public Health Association for water quality. All the laboratory tests were conducted at ambient laboratory temperature of $27 \pm 2^{\circ} \mathrm{C}$, at the Water
Laboratory of Delta State Polytechnic, Ozoro, Nigeria. All tests were replicated five times and the average value recorded.

Data analysis

The results of the water tests were analyzed by employing the SPSS, version 20.

\section{Results and Discussion}

The results from the study are presented in Table 1 . As it can be seen in Table 1, the water quality is highly influence by the abattoir effluent. Table 2 shows the correlation of physiochemical and microbiological properties of the water samples collected at the five spatial points along River Brass.

\begin{tabular}{|l|c|c|c|c|c|c|c|}
\hline \multicolumn{1}{|c|}{ Parameter } & Point of contact & $\begin{array}{c}\mathbf{1 0 ~ m} \\
\text { away }\end{array}$ & $\begin{array}{c}\mathbf{2 0 ~} \mathbf{~ m} \\
\text { away }\end{array}$ & $\begin{array}{c}\mathbf{3 0} \mathbf{~ m} \\
\text { away }\end{array}$ & $\begin{array}{c}\mathbf{5 0} \mathbf{~ m} \\
\text { away }\end{array}$ & $\begin{array}{c}\text { WHO standard } \\
\text { (Maximum Permitted) }\end{array}$ & $\begin{array}{c}\text { NSDWQ (Maximum } \\
\text { Permitted) }\end{array}$ \\
\hline $\mathrm{pH}$ & 7.8 & 7.3 & 6.5 & 6.9 & 6.6 & $6.5-8.5$ & $6.5-8.5$ \\
\hline Cond. $\left(\mu \mathrm{S} \mathrm{cm}^{-1}\right)$ & 165 & 143 & 126 & 131 & 119 & 1000 & 1000 \\
\hline TSS $\left(\mathrm{mg} \mathrm{l}^{-1}\right)$ & 140 & 113 & 85 & 92 & 82 & $\mathrm{NS}$ & NS \\
\hline TDS $\left(\mathrm{mg} \mathrm{l}^{-1}\right)$ & 157 & 183 & 221 & 262 & 273 & 500 & 500 \\
\hline DO $\left(\mathrm{mg} \mathrm{l}^{-1}\right)$ & 1.01 & 1.42 & 3.99 & 3.41 & 3.55 & 2.0 & 2.0 \\
\hline BOD $_{5}$ & 323 & 65 & 56 & 78 & 62 & 10 & NS \\
\hline Coliform count cfu ml & 201 & 92 & 46 & 75 & 34 & 0 & 10 \\
\hline Ammonia $\left(\mathrm{mg} \mathrm{l}^{-1}\right)$ & 4.88 & 4.03 & 2.11 & 1.42 & 0.39 & 0.5 & NS \\
\hline Lead $\left(\mathrm{mg} \mathrm{l}^{-1}\right)$ & 1.09 & 0.88 & 0.73 & 0.71 & 0.63 & 0.01 & 0.01 \\
\hline
\end{tabular}

Table 1: Analysis of water samples at collected at River Brass.

NS: Not Specified.

\begin{tabular}{|l|c|c|c|c|c|c|c|c|c|}
\hline & pH & Cond. & TSS & TDS & DO & BOD $_{5}$ & Coliform count & Ammonia & Lead \\
\hline pH & 1.000 & & & & & & & & \\
\hline Cond. & 0.97 & 1.000 & & & & & & & \\
\hline TSS & 0.98 & 0.993 & 1.000 & & & & & & \\
\hline TDS & -0.81 & -0.892 & -0.89 & 1.000 & & & & & \\
\hline DO & -0.95 & -0.906 & -0.94 & 0.850 & 1.000 & & & & \\
\hline BOD $_{5}$ & 0.83 & 0.882 & 0.873 & -0.68 & -0.69 & 1.000 & & & \\
\hline Coliform count & 0.95 & 0.982 & 0.972 & -0.81 & -0.85 & 0.949 & 1.000 & & \\
\hline Ammonia & 0.88 & 0.932 & 0.927 & -0.98 & -0.89 & 0.692 & 0.851 & 1.000 & \\
\hline Lead & 0.94 & 0.99 & 0.985 & -0.94 & -0.91 & 0.866 & 0.960 & 0.959 & 1.000 \\
\hline
\end{tabular}

Table 2: Correlation analysis of the physiochemical and microbiological properties.

\section{Acidity ( $\mathrm{pH})$}

The $\mathrm{pH}$ concentration of the river water at the various collection points are presented in Table 1 . The results showed a general decreased (more acidity) in the $\mathrm{pH}$ values of the water samples, as we moved from the abattoir effluent discharge point. As shown in Table 1, a pH value of 7.8 was recorded at the discharge point, which could be attributed to the basic nature of effluent. The $\mathrm{pH}$ value declined in a fluctuating form, between the $3^{\text {rd }}$ point and the $5^{\text {th }}$ point, this could be attributed to the discharge from other pollutants (domestic activities) along the river bank. Even though, the water $\mathrm{pH}$ level increased at the $4^{\text {th }}$ point ( $\mathrm{pH}$ 6.9), it dropped again at the $5^{\text {th }}$ point $(6.6)$. Generally, it can be seen that the $\mathrm{pH}$ of the water within the experimental site was slightly acidic. Our result conforms to earlier reports of Omole and Longe [21] on abattoir located at River Illo, Ota, Nigeria; where a $\mathrm{pH}$ range values between 6.20 and 6.90 was recorded. Water $\mathrm{pH}$ plays a vital role in the survival of aquatic biological lives, as they prefer neutral $\mathrm{pH}(\mathrm{pH}$ $=7.0$ ) to more acidic or basic environment [22]. The $\mathrm{pH}$ value of water sample affects the solubility capacity of many chemicals substances, because solubility of many heavy/toxic metals increased as the $\mathrm{pH}$ of the solute (water) decreases. All the $\mathrm{pH}$ values range obtained from the water samples shows that the water falls within the WHO $\mathrm{pH}$ standard level of quality drinking water. 


\section{Electrical conductivity}

Electrical conductivity of the water samples are presented in Table 1. As shown in Table 1, the electrical conductivity of the water samples decreased non-linearly from the discharge point. At the discharge point, an electrical conductivity value of $165 \mu \mathrm{S} \mathrm{cm}^{-1}$ was observed, and then it fluctuates in a decreasing pattern to 119 $\mu \mathrm{S} \mathrm{cm}{ }^{-1}$ at the $5^{\text {th }}$ collection point. Similar results were obtained by Neboh., et al. [4] and Omole and Longe [21]. Omole and Longe [21] observed that the electrical conductivity of River Illo declined from $195 \mu \mathrm{S} \mathrm{cm}^{-1}$ (at the discharge point) to $113 \mu \mathrm{S} \mathrm{cm}^{-1}$ (at $100 \mathrm{~m}$ away from the discharge point).

Electrical conductivity of water is highly dependent on the presence of anions and cations in the water, the water flow rate, the bedrock, etc. The electrical conductivity values obtained from the five points are within the permissible standards recommended by World Health Organization. World Health Organization had recommended a maximum permissible electrical conductivity of $1000 \mu \mathrm{S}$ $\mathrm{cm}^{-1}$ for quality water.

\section{Total dissolved solids (TDS)}

The total dissolved solids (TDS) values of the water samples are presented in Table 1. As shown in Table 1, a TDS value of $157 \mathrm{mg}$ $\mathrm{I}^{-1}$ was recorded at the effluent discharge point, this value generally increased as the water flow downstream, $273 \mathrm{mg} \mathrm{l}^{-1}$ at $50 \mathrm{~m}$ away from the discharge point. The relatively low level of TDS observed in the water samples collected from the five points could be attributed to the ability of the river (water) to carry out self-purification process. The values of the TDS obtained for the water samples collected from the five points, show that the water falls within the WHO TDS standard level (500 $\left.\mathrm{mg} \mathrm{l}^{-1}\right)$ of quality drinking water.

\section{Total suspended solids (TSS)}

Results of the total suspended solid (TSS) of the water samples are presented in Table 1. A seen in Table 1, the TSS concentration declined in a fluctuating pattern, as the water flow away from the discharge point. A TSS concentration of $140 \mathrm{ml}^{-1}$ was recorded as the discharge point, which was the highest TSS concentration value recorded among the five sample points. The high TSS concentration recorded at the discharge point, when compared to the other four collection points, is as a result of the effluent discharged both from the abattoir and adjacent residential areas. As presented in Table 1, between the $3^{\text {rd }}$ sample point and $4^{\text {th }}$ sample point, the TSS value increased from $85 \mathrm{~m} \mathrm{l}^{-1}$ to $92 \mathrm{~m} \mathrm{l}^{-1}$, which could be attributed to the washing of sediments and organic materials into the water from the river bank. This study TSS result is in conformity with earlier study of Omole and Longe [21]. Comparatively, Mittal [23] reported that abattoir effluent contains 2333-8620 $\mathrm{mg} \mathrm{l}^{-1}$ and 736$2099 \mathrm{mg} \mathrm{l}^{-1}$ TSS respectively. As reported by Zubaidah., et al. [24], the addition of additional pollutants from the tributaries that exist between the river segments, can increased the TSS concentrations of the already polluted the river water.

\section{Dissolved oxygen (DO)}

The dissolved oxygen (DO) values of the water samples are presented in Table 1. The results showed that the dissolved oxygen content of the water, decreased gradually as the water flowed downstream away from the discharge point. The declined in the dissolve oxygen content of the water as it flows downstream could also be attributed to the self-purification ability of flowing water. The DO at the effluent discharged point was $1.01 \mathrm{mg}^{-1}$, and slowly increased to $1.42 \mathrm{mg} \mathrm{l}^{-1}$ at the $2^{\text {nd }}$ point, before it sharply inclined to 3.99 at the $3^{\text {rd }}$ point. The sharp increment between the $2^{\text {nd }}$ and $3^{\text {rd }}$ collection points could be attributed to the re-oxygenation tendency of the water to increase its dissolved oxygen level. As shown in Table 1 , the DO concentration at the $2^{\text {nd }}, 3^{\text {rd }}, 4^{\text {th }}$ and $5^{\text {th }}$ points increased linearly, portraying that the dissolved oxygen concentration decrease over distance. Similar results were obtained by Omole and Longe [21], when the DO level increased from $0.1 \mathrm{mg} \mathrm{l}^{-1}$ at the abattoir effluent discharge point, to $3.90 \mathrm{mg} \mathrm{l}^{-1}$ at a point 100 $\mathrm{m}$ away from the point of discharge. The self-purification capabilities of all rivers/streams are not the same, but are highly dependent on water velocity, water discharge volume and initial waste concentration in the river water $[24,25]$. But in contrast Zubaidah., et al. [24] in their research observed that the DO of river water decreased as the water flowed downstream. According to Zubaidah., et al. [24], the DO concentration the water samples collected from a river in Banjarmasin, Indonesia, decreased non-linearly from 5.39 $\mathrm{mg} \mathrm{l}^{-1}$ to $4.10 \mathrm{mg} \mathrm{l}^{-1}$ as the water flows from the point of pollution. Dissolved oxygen is a vital factor which is used to evaluate the water quality; therefore, the higher its concentration, the better the water quality [21].

\section{Biochemical oxygen demand (BOD)}

The results presented in Table 1 showed that the $\mathrm{BOD}_{5}$ was highest at the discharged point and declined downstream. Biochemical oxygen demand indicates the volume of oxygen that bacteria required to stabilize biodegradable materials under aerobic condition. Mean $\mathrm{BOD}_{5}$ of $323 \mathrm{mgl}^{-1}$ was recorded at the discharged point, and this declined to $217 \mathrm{mgl}^{-1}$ that was recorded at $30 \mathrm{~m}$ away from the discharge point (about 33\% decreased). BOD $_{5}$ is a common biochemical parameter used for evaluating the suitability of water for human consumption, because it gives the approximate organic materials in water $[14,26]$. Therefore, water with high $\mathrm{BOD}_{5}$ value is of poor quality and not suitable for drinking, since it contains large amount pollutants (organic materials). Research results have shown that water samples having high $\mathrm{BOD}_{5}$ constituted high risks to animals, vegetation, surface and underground water bodies $[27,28]$. Our study BOD $_{5}$ result conforms to the previous findings of Neboh., et al. [4] and Sumayya., et al. [15]. The inconsistencies in the $\mathrm{BOD}_{5}$ results obtained by the various researchers could be attributed to the initial concentration of the effluent, the volume of the river/stream water, and the flow rate (velocity) of the river/ stream water.

Total coliform count

The coliform test results of the water samples are presented in Table 1. From the results presented in Table 1, the water sample 
collected from the effluent discharged point had the highest coliform count (201 $\mathrm{cfu} \mathrm{ml}^{-1}$ ). The high coliform count (microbial population) obtained from the $1^{\text {st }}$ point of collection, could be attributed to the high nutrient content of the effluent, which served as a good breeding place for the micro-organisms. As the river flows downstream, it was observed from the results that the coliform count decreased significantly; this indicates that the river was trying to purify itself as the water flows downstream. Mittal [23] reported that abattoir effluent contains several million colony forming units (cfu) $/ 100 \mathrm{ml}$ of total coliform, fecal coliform, and Streptococcus groups of bacteria. Going by the results obtained from the five collections points used in this study, the river water was contaminated beyond the level that it is either fit for domestic use without proper treatment. The World Health Organization recommends a permissible coliform count of $0 \mathrm{cfu} \mathrm{ml}^{-1}$ for water met for domestic use and human consumption.

\section{Lead}

The lead concentration of the samples is presented in Table 1. With reference to the results presented in Table 1, the effluent had significant effect on the water body. The highest lead concentration (1.09 $\mathrm{mg} \mathrm{l}^{-1}$ ) was recorded at the effluent discharge point, and declined linearly as the water flows downstream to 0.63 at $50 \mathrm{~m}$ away from the discharge point. Results obtained from this study showed that the mean lead concentration was far above the WHO permissible limit of $0.01 \mathrm{mg} \mathrm{l}^{-1}$ for water quality met for domestic use. Studies have shown that high dosage (above permissible limit) of lead intake into the human body can lead to lead poisoning which is a serious health issue.

\section{Ammonia}

The results of the ammonia concentration of the water samples are presented in Table 1. According to the results obtained from this study, the ammonia concentration of the water samples decreased as the water flows downstream. From the results, the highest ammonia concentration (4.88 $\mathrm{mg} \mathrm{l}^{-1}$ ) was recorded at the abattoir effluent discharge point, and it decreased significantly between the $3^{\text {rd }}$ and $5^{\text {th }}$ collection points. The decline in the ammonia concentration between the $3^{\text {rd }}$ and $5^{\text {th }}$ sample collection points could be attributed to the dilution of the ammonia concentration by the water body (self-purification). Microbial (sewage and animal waste) pollution is the major cause of ammonia presence found in water bodies [29]. Furthermore, the results showed that the river water collected at $50 \mathrm{~m}$ away from the discharge point, falls below the WHO recommended maximum permissible value of $0.5 \mathrm{mg} \mathrm{l}^{-1}$. Therefore, at a distance of $50 \mathrm{~m}$ away from the discharge point, the water quality is falls within WHO standard for drinking water (quite safe), with respect to ammonia pollution. Similar results were observed by Omole and Longe [21], for abattoir effluent discharged into River Illo, Nigeria. In their [21] results, within a distance of $100 \mathrm{~m}$ from the discharged point, the ammonia concentration dropped to $0.11 \mathrm{mg} \mathrm{l}^{-1}$ from $4.40 \mathrm{mg} \mathrm{l}^{-1}$. According to International Organization for Standardization (1986), high concentration of ammonia in water is an important indicator of faecal pollution. Exposing the body to high ammonia level (dose) had harmful effects. When taken at a higher dosage, above $100 \mathrm{mg} \mathrm{kg}^{-1}$ of the body weight per day; it influences the body metabolism by altering its' acid-base equilibrium, distorting the body glucose tolerance, and reduced the tissues sensitivity to insulin [29,30]. From the results of this study, it can be seen that the abattoir effluent had adverse effects on the River Brass, and the inhabitants of the Swali area. Therefore, it is mandatory to treat all the effluents from the abattoir properly before they are discharged into the environment in order to prevent pollution of the water bodies. Aquatic plants and animals that exist in the water bodies are greatly affected by the contaminants through over flow or seepage into improperly constructed surface and ground water systems due to pollutants from organic compounds and biological matter that could exhibit toxic effect on aquatic life and the public [12,31-34].

\section{Conclusion}

This study was conducted to evaluate the effect of abattoir effluent on the Microbiological and physicochemical properties of River Brass, located in Bayelsa State. Results obtained from this study showed impairment in the water quality of River Brass caused by the indiscriminate discharge of an abattoir effluent into the river. The concentration of total suspended solid $\left(140 \mathrm{mg} \mathrm{l}^{-1}\right)$, dissolved oxygen (1.01 $\left.\mathrm{mg} \mathrm{l}^{-1}\right)$, biochemical oxygen demand (323 $\left.\mathrm{mg} \mathrm{l}^{-1}\right)$, total coliform count (201 $\left.\mathrm{cfu} \mathrm{ml}^{-1}\right)$, lead $1.09 \mathrm{mg} \mathrm{l}^{-1}$ ) and Ammonia ( $4.88 \mathrm{mg} \mathrm{l}^{-1}$ ) was recorded at the abattoir effluent discharge point, which comparatively higher when compared with the results obtained from water samples collected at $50 \mathrm{~m}$ away from the discharge point. The values obtained for TSS, D0, BOD5, lead and total coliform count was above the permissible limits recommended by WHO and NSDWQ for water quality suitable for domestic consumption. Improvement observed in the water quality as it flows downstream was due to the self-purification capability of the river. In conclusion, the high level of contamination in the river water resulted from the discharged of untreated abattoir effluent into water body. Therefore, it is recommended that the abattoir effluent should be propertied treated before it is discharged into the environment to prevent environmental pollution, mostly the water bodies.

\section{Bibliography}

1. Abattoir Acts. Slaughter house cleaning and sanitation. FAO Animal Production and Health Paper 53. Rome, Italy (1985).

2. Abubakar GA and Tukur A. "Impact of abattoir effluent on soil chemical properties in Yola, Adamawa state, Nigeria”. International Journal of Sustainable Agricultural Research 1.4 (2014): 100-107.

3. Nafarnda WD., et al. "Bacteriological quality of Abattoir effluents discharged into water bodies in Abuja, Nigeria". International Scholarly Research Network (2012): 1-6.

4. Neboh HA., et al. "Assessment of ijebu-igbo abattoir effluent and its impact on the ecology of the receiving soil and river". Journal of Science, Toxicology and Food Technology 7.5 (2013): 2319-2402. 
5. Nafarnda WD., et al. "Impact of abattoir waste on aquatic life: a case study of Yola abattoir". Global Journal of Pure and Applied Sciences 12 (2006): 31-33.

6. WHO - World Health Organization of the United Nations. Guidelines for Drinking-water Quality Geneva, 3rd Edition 1 (2019).

7. Behr P. “Looming water crisis”. CQ Global Researcher 2 (2008): 27-56.

8. The New Humanitarian. "Officials fear cholera resurgence in north" (2009).

9. WHO - World Health Organization of the United Nations. Drinking-water (2018).

10. Ahmad H and Saadieh WE. "Water quality assessment of Lebanese coastal rivers during dry season and pollution load into the Mediterranean Sea". Journal of Water Health 5.4 (2017): 615-623.

11. Akpokodje OI., et al. "Remediation of cassava effluent contaminated soil using organic soap solution: Case study of soil physical properties and plant growth performance". Journal of Scientific Research and Reports 21.3 (2018): 1-11.

12. Onifade TB., et al. "Assessment of cassava waste effluent effect on some water sources in Ilorin, Nigeria". African Journal of Engineering Research 3.3 (2018): 56-68.

13. Eboibi 0., et al. "Bioremediation of soil contaminated with cassava effluent using organic soap solution". Journal of Environmental Science, Toxicology and Food Technology 12 (2018): 50-57.

14. Uguru $\mathrm{H}$ and Obah GE. "Remediation of effluent from cassava processing mills". Journal of Public Health and Environmental Technology 4.4 (2019): 21-25.

15. Sumayya BU., et al. "Determination of physiochemical qualities of abattoir effluent on soil and water in Gandu, Sokoto State". Journal of Environmental Science, Toxicology and Food Technology 4.4 (2013): 47-50.

16. Ako Ako A., et al. "Nitrate contamination of groundwater in two areas of the Cameroon volcanic line Banana plain and Mount Cameroon area". Applied Water Science 4 (2014): 99113.

17. Rabah AB., et al. "Microbiological and physicochemical assessment of soil contaminated with abattoir effluents in Sokoto metropolis, Nigeria". Science World Journal 5.3 (2010): 1-4.

18. Google map. Swali Map (2019).

19. Eboibi O., et al. "Evaluation of textural qualities and chemical properties of some tomato cultivars". Direct Research Journal of Agriculture and Food Science 7.6 (2019): 147-157.
20. APHA - American Public Health Association. In: Eaton AD, Clescer LS, Rice EW, Greenberg AE, Franson MAH (eds.) Standards Methods for examination of waters and wastewaters APHA 21st edition Washington DC (2005): 1368.

21. Omole DO and Longe EO. "An Assessment of the Impact of Abattoir Effluents on River Illo, Ota, Nigeria". Journal of Environmental Science and Technology 1 (2008): 56-64.

22. Dallas LJ and Jha AN. "Applications of biological tools or biomarkers in aquatic biota: A case study of the Tamar estuary, South West England". Marine Pollution Bulletin, The English Channel and its catchments: Status and Responses to Contaminants 95 (2015): 618-633.

23. Mittal GS. "Characterization of the effluent wastewater from abattoirs for land application". Food Reviews International 20 (2004): 229-256.

24. Zubaidah T., et al. "The self-purification ability in the rivers of Banjarmasin, Indonesia". Journal of Ecological Engineering 20.2 (2019): 177-182.

25. Effendi H. "River Water Quality Preliminary Rapid Assessment Using Pollution Index. Procedia Environmental Sciences”. The 2nd International Symposium on LAPAN-IPB Satellite (LISAT) for Food Security and Environmental Monitoring 33 (2012): 562-567.

26. Al-Turki AI. "Assessment of effluent quality of tertiary wastewater treatment plant at buraidah city and its reuse in irrigation". Journal of Applied Science 10 (2010): 1723-1731.

27. Isabirye M., et al. "Soil losses due to cassava and sweet potatoes harvesting: A case study from low in put traditional agriculture". Soil Tillage Resource 92 (2007): 96-103.

28. Ugwu EI and Agunwamba JC. "Detoxification of cassava wastewater by alkali degradation". Journal of Research in Environmental Science and Toxicology 1.7 (2012): 161-167.

29. WHO - World Health Organization of the United Nations. "Ammonia in drinking-water. Background document for preparation of WHO Guidelines for drinking-water quality". Geneva, World Health Organization (WHO/SDE/WSH/03.04/1) (2003).

30. EPA - Environmental Protection Agency. Summary review of health effects associated with ammonia. Washington, DC, US Environmental Protection Agency, (EPA/600/8-89/052F) (1989).

31. United Nations Environment Programme - UNEP. "Water Quality Monitoring - A Practical Guide to the Design and Implementation of Freshwater Quality Studies and Monitoring Programmes" (1996). 
32. Egharevba F and Odjada V. "The pollution potential and chemical interaction parameter of some agro and industrial wastes on soils". Nigerian Journal of Basic and Applied Sciences 11 (2002): 177-188.

33. NSDWQ - Nigerian Standard for Drinking Water Quality. Draft version 2. 22. Federal Ministry of Health (2007).

34. Osakwe AA. "Effect of cassava processing mill effluent on physical and chemical properties of soils in Abraka and environs, Delta State, Nigeria". Chemistry and Materials Research 2.7 (2012): 27-39.

\section{Assets from publication with us}

- Prompt Acknowledgement after receiving the article

- Thorough Double blinded peer review

- Rapid Publication

- Issue of Publication Certificate

- High visibility of your Published work

Website: https://www.actascientific.com/

Submit Article: https://www.actascientific.com/submission.php Email us: editor@actascientific.com

Contact us: +919182824667 